\title{
STATUS RESISTENSI LARVA AEDES SP TERHADAP LARVASIDA SEBAGAI FAKTOR RISIKO KEJADIAN DEMAM BERDARAH DENGUE DI WILAYAH BUFFER PELABUHAN LAUT TANJUNG PERAK SURABAYA
}

\author{
Fawandi Eta Rachmawati \\ Kesehatan Lingkungan, Universitas Airlangga \\ Email: etarachma@gmail.com
}

\begin{abstract}
Both land and air ports as well as entry points for people, tools and goods are also vector transportation media that cause disease in the cycle of transmission of disease to humans, especially dengue fever. Disease vector (Aedes aegypti) can move from endemic areas to other areas due to being carried away by goods or transport equipment from activities at the port. The 2005 IHR stated that the port perimeter area must be free from larvae with the House Index $(H I)=0$. In the buffer area of the House Index (HI) value> 1, if it exceeds that number, vector control measures are required. From this phenomenon, the researcher wants to know the resistance status of Aedes Sp larvae in the buffer zone of Tanjung Perak Surabaya. The research is pure experiment with the design of Postest Only with Control Group Design, using the WHO susceptibility test method. Data retrieval uses a purposive sampling method in the buffer zone of Tanjung Perak port. The number of larvae that died during the experiment was calculated using LC 50, LC 90 and LC 99 using Probit test logistic regression, so that the value of Resistance Ratio (RR) RR value of Aedes Sp larvae in the buffer region included in the category of moderate to moderate resistance. The use of larvacide temephos can still be used in buffer areas, but it is necessary to educate the public in the port area to be able to use larvacida safely and effectively.
\end{abstract}

Keywords: Resistance, Aedes Sp., Dengue Fever, Larvacida

\begin{abstract}
ABSTRAK
Pelabuhan baik darat maupun udara selain sebagai pintu masuk orang, alat dan barang juga sebagai media transportasi vektor penyebab penyakit dalam siklus penularan penyakit pada manusia khususnya penyakit demam berdarah. Vektor penyakit (Aedes aegypti) dapat berpindah dari daerah endemis ke daerah lain akibat terbawa oleh barang atau alat angkut dari adanya aktifitas di pelabuhan. IHR 2005 menyatakan wilayah perimeter pelabuhan harus terbebas dari jentik dengan House Index $(\mathrm{HI})=0$. Pada wilayah buffer nilai House Index $(\mathrm{HI})>1$, jika melebihi dari angka tersebut maka diharuskan melakukan upaya pengendalian vektor. Dari fenomena tersebut peneliti ingin mengetahui status resistensi dari larva Aedes $S p$ di wilayah buffer pelabuhan Tanjung Perak Surabaya. Penelitian bersifat eksperimen murni dengan rancangan Postest Only with Control Group Design menggunakan metode susceptibility test WHO. Pengambilan data menggunakan metode purposive sampling di wilayah buffer pelabuhan Tanjung Perak. Jumlah larva yang mati saat percobaan dilakukan perhitungan nilai LC 50, LC 90 dan LC 99 menggunakan regresi logistik Probit test, sehingga dapat diketahui nilai Resistance Ratio (RR) Nilai RR larva Aedes $S p$ di wilayah buffer termasuk dalam kategori rentan hingga resisten sedang. Penggunaan larvasida temephos masih bisa dilakukan di
\end{abstract}


wilayah buffer, namun perlu upaya edukasi kepada masyarakat di wilayah pelabuhan agar dapat menggunakan larvasida dengan aman dan tepat guna.

Kata kunci: Resistensi, Aedes Sp., Demam Berdarah Dengue, Larvasida

\section{PENDAHULUAN}

Aedes aegypti merupakan salah satu vektor yang paling aktif menularkan Demam Berdarah Dengue. Vektor ini memiliki perindukan yang berada di sekitar rumah, serta memiliki siklus hidup yang tergantung pada darah manusia. Perilaku tersebut mengakibatkan Aedes aegypti memiliki kemampuan menularkan virus dengue yang tinggi karena kebiasaan nyamuk untuk menghisap darah manusia berulang pada pagi dan sore hari. ${ }^{1}$ Penyakit DBD yang terjadi di Indonesia, ditemukan pertama kali di Surabaya. Sejumlah 58 orang terinfeksi dan 24 orang meninggal dunia dengan angka kematian sebesar 41,3\%. Berdasarkan profil kesehatan Indonesia tahun 2016, Jawa Timur menduduki peringkat 15 tertinggi kasus DBD dengan jumlah kasus sebanyak 24.005 kasus, nilai Incidence Rate (IR) per 100.000 penduduk sebesar $61,43 \%$, dan nilai Case Fatality Rate (CFR) sebesar $1,42 \%$ dari 340 jumlah kasus meninggal. $^{2}$

Pelabuhan baik laut maupun udara merupakan tempat pertemuan atau aktifitas perdagangan keluar dan masuknya barang, orang dan juga alat angkut. Beragam aktifitas tersebut sangat memungkinkan bagi vektor penyakit ini, yaitu Aedes aegypti untuk dapat berpindah dari daerah endemis ke daerah lain.
Perpindahan vektor dapat berakibat meningkatnya risiko penyakit tular vektor pada daerah baru apabila menemukan reservoar dan lingkungan yang sesuai di tempat baru. Keputusan Menteri Kesehatan No. 431 tentang Pengendalian Resiko Kesehatan Lingkungan di Pelabuhan/Bandara/ Pos Lintas Batas dalam Rangka Karantina Kesehatan angka House Index (HI) Aedes aegypti di dalam wilayah buffer kurang dari $1 \%$, dengan membatasi populasi dari nyamuk di lingkungan pelabuhan. Untuk wilayah perimeter, tidak boleh terdapat nyamuk Aedes aegypti baik stadium larva ataupun stadium dewasa. Kantor Kesehatan Pelabuhan dituntut untuk dapat melaksanakan dekontaminasi serta upaya pengendalian vektor dan reservoar terhadap alat angkut. ${ }^{3}$ Hal ini bertujuan untuk mencegah terjadinya penyakit global yang bersifat darurat dan menjadi perhatian dunia yang disebabkan oleh lalu lintas alat angkut yang masuk dan keluar melalui pelabuhan. IHR 2005 juga menyebutkan bahwa setiap pelabuhan laut dan udara harus bebas dari nyamuk Aedes aegypti baik jentik maupun nyamuk dewasa. Permenkes No. 44 Tahun 2014 menyatakan bahwa dalam menyelenggarakan pelabuhan sehat harus memenuhi beberapa kriteria dan indikator, salah satu indikatornya adalah pelabuhan harus bebas jentik. 
Upaya pengendalian Aedes aegypti yang telah dilakukan oleh berupa larvasidasi, fogging dan penyuluhan yang dilaksanakan secara terintegrasi. Kegiatan pengendalian vektor tersebut dilaksanakan secara periodik dan terjadwal yang diawali dengan kegiatan survei jentik dan larvasidasi kemudian disusul dengan kegiatan pemberantasan nyamuk dewasa atau fogging. ${ }^{4}$ House Index tertinggi terdapat pada 3 wilayah yaitu Pelabuhan Laut Tanjung Perak, Pelabuhan Laut Gresik dan Bandar Udara Internasional Juanda, dimana wilayah Pelabuhan Laut Tanjung Perak memiliki frekuensi kegiatan pengendalian vektor yang lebih banyak dibanding wilayah kerja yang lain. House Indeks (HI) yang lebih dari $1 \%$ berpotensi memengaruhi kepadatan jentik Aedes aegypti, sebagai faktor risiko penularan penyakit DBD yang disebabkan oleh nyamuk Aedes aegypti.

Peraturan yang mewajibkan pelabuhan harus bebas dari jentik dan upaya pengendalian yang dilaksanakan secara kontinyu dalam kurun waktu yang lama, tentunya akan memicu adanya kekebalan vektor terhadap insektisida. Larva Aedes aegypti dari wilayah buffer Pelabuhan Tanjung Emas, rerata kematian larva sebesar $68 \%$ dinyatakan telah resisten terhadap temephos. ${ }^{5}$ Selain pada fase larva, resistensi terhadap insektisida juga ditemukan pada fase dewasa. Uji kerentanan nyamuk Aedes aegypti terhadap malation $(0,8 \%)$ pada empat kelurahan/ desa di wilayah kerja KKP Manado menunjukkan adanya resistensi. Kematian nyamuk sebesar
$0 \%$ yang ditandai dengan adanya peningkatan enzim esterase non spesifik. ${ }^{6}$ Hal ini tentunya sangat berisiko dalam terjadinya penyebaran penyakit karena lokasi pelabuhan berdekatan dengan pemukiman.

Penggunaan bubuk larvasida yang kurang tepat baik dari segi takaran, frekuensi dan lama waktu memicu kerentanan larva terhadap larvasida. Pemaparan dalam dosis yang tidak terukur dalam waktu yang berulang berpotensi meningkatkan kekebalan larva terhadap larvasida yang digunakan. Resitensi serangga terhadap suatu insektisida akan terjadi apabila digunakan secara intensif selama 2 sampai 20 tahun dan terus menerus sepanjang tahun. ${ }^{7}$

Tujuan dari penelitian ini adalah untuk mengetahui status resistensi dari larva Aedes $S p$ di wilayah buffer pelabuhan Tanjung Perak Surabaya sebagai faktor risiko kejadian Demam Berdarah Dengue di wilayah pelabuhan.

\section{METODE PENELITIAN}

Penelitian eksperimental murni dengan rancangan Postest Only with Control Group Design menggunakan metode susceptibility test WHO. Dosis yang digunakan adalah 0,01; 0,02; 0,03; 0,04; 0,05; 0,08 dan 1 ppm. ${ }^{8}$ Percobaan dilakukan dengan melihat kematian larva uji dan menghitung nilai Lethal Concentration (LC). Nilai LC yang dihitung yaitu LC 50, LC 90, dan LC 99 menggunakan analisis regresi logistik probit-test. Nilai LC tersebut digunakan untuk menghitung nilai Resistance Ratios (RR) dengan 
cara membandingkan nilai LC 50 nyamuk lapangan dan nilai LC 50 nyamuk laboratorium. Nilai RR dikelompokkan menjasi 3 kategori, yaitu rentan, resisten sedang dan resisten. ${ }^{9}$

Teknik pengambilan sampel menggunakan purposive sampling, dengan cara menjadikan daerah sporadis sebagai wilayah penelitian. Cara pengambilan sampel sebanyak 100 rumah dengan mengambil radius sejauh 100-200 meter dari rumah penderita sesuai dengan jarak terbang terjauh nyamuk Aedes $S p$. Pengambilan sampel dilakukan dengan memasang perangkap telur (ovitrap) pada rumah responden selama 7 hari. Ovitrap yang dipasang dengan menambahkan bubuk pelet ikan sebagai penarik nyamuk untuk bertelur karena tingginya zat organik dalam air dari penambahan pelet tersebut. ${ }^{10}$ Ovitrap dibuat berwarna gelap dan diletakkan pada tempat yang gelap sesuai dengan sifat dari nyamuk betina saat beristirahat. ${ }^{11}$ Ovitrap diambil setelah 7 hari, kemudian melakukan rearing telur nyamuk untuk dibiakkan menjadi larva di Laboratorium. Larva yang dilakukan pengujian merupakan larva instar 3 akhir atau larva instar 4 awal dan selanjutnya dilakukan susceptibility test sesuai prosedur dari WHO. ${ }^{12}$

Pemasangan ovitrap digolongkan berdasarkan dasawisma lokasi pemasangan, hal ini bertujuan untuk mempermudah perhitungan dan analisis dari status resistensi larva Aedes Sp. Hasil penelitian disampaikan dalam bentuk tabel dan di deskripsikan untuk dilakukan analisis.

\section{HASIL DAN PEMBAHASAN}

Hasil perhitungan dan analisis dari status resistensi dari larva Aedes $S p$ di wilayah buffer pelabuhan Tanjung Perak Surabaya sebagai faktor risiko kejadian Demam Berdarah Dengue di wilayah pelabuhan.

Tabel 1. Distribusi Kematian Larva Uji Resistensi Terhadap Larvasida

\begin{tabular}{lllllllll}
\hline \multirow{2}{*}{ No. } & \multirow{2}{*}{ Lokasi } & \multicolumn{6}{c}{ Kematian Larva (\%) Per Konsentrasi (ppm) } \\
\cline { 3 - 8 } & 0,01 & 0,02 & 0,03 & 0,04 & 0,05 & 0,08 & 1 \\
\hline 1 & Dasawisma 1 & $40^{\mathrm{C}}$ & $51^{\mathrm{C}}$ & $55^{\mathrm{C}}$ & $64^{\mathrm{C}}$ & $66^{\mathrm{C}}$ & $81^{\mathrm{B}}$ & $93^{\mathrm{B}}$ \\
2 & Dasawisma 2 & $36^{\mathrm{C}}$ & $46^{\mathrm{C}}$ & $51^{\mathrm{C}}$ & $56^{\mathrm{C}}$ & $64^{\mathrm{C}}$ & $80^{\mathrm{B}}$ & $90^{\mathrm{B}}$ \\
3 & Dasawisma 3 & $39^{\mathrm{C}}$ & $51^{\mathrm{C}}$ & $56^{\mathrm{C}}$ & $61^{\mathrm{C}}$ & $65^{\mathrm{C}}$ & $85^{\mathrm{B}}$ & $91^{\mathrm{B}}$ \\
4 & Dasawisma 4 & $35^{\mathrm{C}}$ & $46^{\mathrm{C}}$ & $53^{\mathrm{C}}$ & $59^{\mathrm{C}}$ & $66^{\mathrm{C}}$ & $83^{\mathrm{B}}$ & $89^{\mathrm{B}}$ \\
5 & Dasawisma 5 & $43^{\mathrm{C}}$ & $53^{\mathrm{C}}$ & $56^{\mathrm{C}}$ & $63^{\mathrm{C}}$ & $69^{\mathrm{C}}$ & $81^{\mathrm{B}}$ & $90^{\mathrm{B}}$ \\
6 & Dasawisma 6 & $40^{\mathrm{C}}$ & $53^{\mathrm{C}}$ & $55^{\mathrm{C}}$ & $58^{\mathrm{C}}$ & $64^{\mathrm{C}}$ & $85^{\mathrm{B}}$ & $93^{\mathrm{B}}$ \\
7 & Laboratorium & $80^{\mathrm{B}}$ & $83^{\mathrm{B}}$ & $88^{\mathrm{B}}$ & $89^{\mathrm{B}}$ & $91^{\mathrm{B}}$ & $94^{\mathrm{B}}$ & $99^{\mathrm{A}}$ \\
\hline
\end{tabular}

Status Kerentanan Berdasar Kematian : ${ }^{A}$ Rentan ( $\left.\geq 98 \%\right),{ }^{B}$ Toleran / resisten sedang (80-98\%), ${ }^{C}$ Resisten $(<80) .{ }^{9}$ Nilai Persentase adalah hasil pembulatan 
Pada Tabel 1 diatas dapat disimpulkan bahwa berdasarkan jumlah kematian larva, larva uji dari wilayah penelitian telah resisten pada konsentrasi $0,01 \mathrm{ppm}-0,05 \mathrm{ppm}$. Pada konsentrasi 1ppm atau dosis lapangan di Indonesia, larva uji dari wilayah penelitian dikategorikan toleran atau resisten sedang. Sedangkan pada larva uji yang berasal dari laboratorium, termasuk dalam kategori rentan hingga toleran atau resisten sedang. Konsentrasi larvasida dengan jumlah kematian terbanyak terdapat pada konsentrasi atau dosis lapangan di Indonesia (1mg/l) dengan jumlah kematian larva antara 18-20 larva yang mati. Berdasarkan jumlah kematian larva, dosis lapangan di Indonesia masih toleran terhadap larva uji dari wilayah penelitian, dan dinyatakan rentan pada larva uji yang berasal dari laboratorium. Dosis lapangan penggunaan temephos $1 \%$ berdasarkan prosedur WHO Tahun 2015 (0,02mg/l), pada percobaan ini larva pada wilayah penelitian telah menunjukkan resisrtensi. Larva uji yang berasal dari laboratorium juga telah menunjukkan resistensi ringan atau toleran. Pada tabel diatas juga dapat disimpulkan bahwa semakin tinggi konsentrasi larvasida, semakin banyak jumlah kematian larva.

Status resistensi pada wilayah penelitian ini didukung dengan sebuah penelitian yang menyatakan semua larva Aedes $S p$ pada seluruh strain di wilayah Surabaya telah resisten pada konsentrasi WHO (0,02ppm). ${ }^{13}$ Pada konsentrasi 1ppm, resistensi berdasar kematian memiliki hasil yang beragam, yaitu pada kategori resisten dan toleran. Strain dengan jumlah kematian tertinggi pada konsentrasi 1ppm terdapat pada wilayah Surabaya Utara (Kenjeran dan Bulak), dan yang dinyatakan resisten pada daerah Tambaksari, Gubeng dan Sawahan.

Setelah dilakukan perhitungan jumlah larva yang mati pada saat dilakukan percobaan, maka dilakukan perhitungan probit dengan menggunakan software SPSS untuk menghitung LC 50, LC 90, dan LC 99 untuk kemudian menghitung resisten rasio. Resisten rasio diperoleh dengan cara membagi LC 50 larva lapangan dengan LC 50 larva laboratorium. Hasil perhitungan tersebut digambarkan pada tabel berikut:

Tabel 2. Distribusi Nilai LC dan RR

\begin{tabular}{llcccc}
\hline \multirow{2}{*}{ No. } & Lokasi & \multicolumn{2}{c}{ Nilai Lethal Concentration (LC) } & \multirow{2}{*}{ Resistance Ratio (RR) } \\
\cline { 3 - 5 } & & 50 & 90 & 99 & \\
\hline \hline 1 & Dasawisma 1 & 0,017 & 0,429 & 5,875 & $4,25^{\mathrm{A}}$ \\
2 & Dasawisma 2 & 0,022 & 0,607 & 8,907 & $5,5^{\mathrm{B}}$ \\
3 & Dasawisma 3 & 0,017 & 0,452 & 6,441 & $4,25^{\mathrm{A}}$ \\
\hline
\end{tabular}




\begin{tabular}{llcccl}
\hline \multirow{2}{*}{ No. } & Lokasi & \multicolumn{2}{c}{ Nilai Lethal Concentration (LC) } & \multirow{2}{*}{ Resistance Ratio (RR) } \\
\cline { 3 - 5 } & & 50 & 90 & 99 & \\
\hline \hline 4 & Dasawisma 4 & 0,021 & 0,589 & 8,943 & $5,25^{\mathrm{B}}$ \\
5 & Dasawisma 5 & 0,015 & 0,585 & 11,676 & $3,75^{\mathrm{A}}$ \\
6 & Dasawisma 6 & 0,018 & 0,435 & 5,802 & $4,5^{\mathrm{A}}$ \\
7 & Laboratorium & 0,004 & 0,14 & 0,36 & - \\
\hline
\end{tabular}

Resistance Ratios: ${ }^{A}$ Rentan $(R R<5),{ }^{B}$ Re sisten sedang (RR 5-10), ${ }^{C}$ Resisten (RR >10). ${ }^{9}$

Berdasarkan Tabel 2 diatas, dapat disimpulkan bahwa larva yang berasal dari wilayah penelitian dinyatakan masih rentan terhadap konsentrasi larvasida abate yang memiliki bahan aktif temephos $1 \%$. Nilai LC adalah konsentrasi optimal yang dapat mematikan larva uji sebanyak 50\%,90\%, atau 99\% dari total populasi uji. Populasi larva yang berasal dari laboratorium tidak memiliki nilai LC karena hanya berperan sebagai pembagi dalam menghitung resisten rasio larva dari wilayah penelitian.

\section{Analisis Faktor Risiko Demam Berdarah}

\section{Dengue Oleh Vektor di Wilayah Pelabuhan}

Metode pengendalian DBD bersifat lokal dengan mempertimbangkan faktor pendukung terjadinya kasus yaitu vektor, lingkungan fisik (cuaca, kualitas pemukiman, habitat perkembangbiakan), perilaku inang (manusia), meliputi sosial budaya (pengetahuan, sikap dan praktik). ${ }^{14}$ Penelitian ini memiliki fokus pada vektor yang menjadi pembawa virus penyebab DBD. Status resistensi larva Aedes $S p$ terhadap larvasida yang ada di wilayah buffer bervariasi, mulai dari rentan hingga resisten sedang. Secara epidemiologi, pola penyebaran penyakit DBD berdasarkan kemampuan terbang nyamuk, yaitu dalam radius $50 \mathrm{~m}-100 \mathrm{~m}$ dari rumah penderita. ${ }^{15}$ Jarak terbang maksimal nyamuk yang pendek, mengakibatkan vektor di wilayah dengan radius tersebut memiliki karakter yang sama. Hal ini disebabkan habitat dan perindukan vektor terjadi pada wilayah yang berdekatan juga. Fenomena ini dapat dilihat dari nilai RR (Tabel.2) yang memiliki kecenderungan homogen.

Mayoritas status resistensi menunjukkan larva masih dalam kategori rentan terhadap larvasida. Adanya beberapa dasawisma dengan status resistensi resisten sedang dapat menjadi salah satu faktor risiko meningkatnya status resistensi. Hal ini diakibatkan oleh perkembangbiakan dan pola penyebaran vektor Aedes $S p$ yang sempit akibat jarak terbang terjauh yaitu 50-100m. Penyebaran Aedes Sp. dipengaruhi oleh kepadatan pen-duduk, jarak antar rumah memengaruhi penyebaran nyamuk dari satu rumah ke rumah lain. Semakin dekat jarak antar rumah, semakin mudah penyebaran penyakit DBD oleh vector. ${ }^{16}$ 
Larva yang resisten tentunya menjadi salah satu faktor risiko tingginya kepadatan larva di wilayah buffer pelabuhan. Penelitian Mulyowati menyatakan bahwa resistensi larva terhadap insektisida memiliki pengaruh terhadap angka kepadatan larva Aedes aegypti di Kecamatan Pati. ${ }^{17}$ Kepadatan larva dapat diartikan sebagai suatu indikator potensi risiko penyebaran penyakit dengue. Semakin tinggi angka kepadatan larva, maka semakin besar potensi risiko masyarakat di wilayah tersebut untuk kontak dengan pembawa virus dengue. Kepadatan larva memilki banyak faktor penyebab, hal ini disebabkan DBD terjadi karena didukung oleh beberapa komponen, yaitu pembawa penyakit vektor, penyebab penyakit (virus), lingkungan fisik dan manusia. ${ }^{18}$ Rumah dengan kondisi lingkungan fisik yang memadai untuk perkembangbiakan vektor tentunya akan berisiko tinggi untuk menjadi tempat perindukan vektor DBD di lingkungan rumahnya.

Pemutusan rantai penularan oleh vektor, dapat dilakukan dengan menghindari atau mengurangi kontak terhadap nyamuk, membunuh larva nyamuk dan menghilangkan tempat perindukan nyamuk. Upaya yang masif dilakukan oleh penyelenggara kesehatan berupa PSN, dengan harapan dapat memampukan masyarakat untuk melindungi lingkungan dan keluarga dari risiko DBD.

Suatu strategi yang menyeluruh dari berbagai pihak diperlukan untuk menurunkan faktor risiko penularan oleh vektor, antara lain dengan meminimalkan habitat perkembangbiakan vektor, menurunkan kepadatan dan umur vektor, mengurangi kontak antara vektor dengan manusia, serta memutus rantai penularan. Upaya tersebut tentunya harus dilakukan dengan baik dan terintegrasi untuk hasil yang optimal. Pemberdayaan masyarakat tentunya sangat membantu dalam keberhasilan program suatu penyelenggara kesehatan. Perubahan perilaku hidup bersih dan sehat tentunya dapat membantu memutus mata rantai penularan suatu penyakit menular. Perilaku yang berdasar pengetahuan akan lebih bertahan daripada yang tidak berdasar pengetahuan. ${ }^{19}$ Penambahan informasi sangat diperlukan untuk merubah perilaku dan persepsi masyarakat akan pencegahan dan penanggulangan DBD. Peran serta tenaga kesehatan sangat diperlukan dalam memberikan penyuluhan, kursus singkat kepada masyarakat, atau pelatihan khusus terhadap kader. Kerjasama lintas sektor kesehatan di wilayah pelabuhan, dalam memampukan masyarakat terkait pencegahan dan penanggulangan DBD sangat diperlukan. Informasi dan pengetahuan masyarakat yang baik terhadap tata cara penggunaan larvasida yang tepat dan aman, yang bertujuan untuk mengurangi risiko meningkatnya status resistensi larva terhadap larvasida juga sangat diperlukan. Rangkaian upaya tersebut berguna untuk mendorong masyarakat dalam berpartisipasi aktif, dan berkesinambungan dalam kegiatan pemberantasan sarang nyamuk di lingkungannya. 


\section{SIMPULAN DAN SARAN}

\section{Simpulan}

Status resistensi larva Aedes Sp di wilayah buffer Pelabuhan Laut Tanjung Perak termasuk dalam kategori rentan hingga moderate atau resisten sedang. Adanya hasil uji dengan kategori moderate atau resisten sedang, menunjukkan adanya faktor risiko terjadi DBD oleh vektor di wilayah pelabuhan. Larvasida yang digunakan oleh masyarakat saat ini, masih aman untuk dipergunakan.

\section{Saran}

Pemberian tambahan informasi terkait cara penggunaan larvasida yang tepat dan aman kepada masyarakat. Hal tersebut bertujuan untuk meminimalkan faktor risiko meningkatnya status resistensi larva terhadap larvasida yang telah digunakan.

\section{REFERENSI}

1. Yudhastuti, R. Pengendalian Vektor dan Rodent. Surabaya: Pustaka Melati. 2011.

2. Kemenkes RI. Data dan Informasi Profil Kesehatan Indonesia 2016. Jakarta: Pusat Data dan Informasi Kemenkes RI. 2017.

3. WHO. International Health Regulations 2005 Second Edition. Switzerland: World Health Organization. 2007.

4. KKP Kelas I Surabaya Laporan Tahunan Kantor Kesehatan Pelabuhan Kelas I Surabaya Tahun 2017. Surabaya: KKP Kelas I Surabaya. 2017.

5. Handayani, N. L. S. Status Resistensi Larva Aedes aegypti Terhadap Temephos Di Wilayah Perimeter dan Buffer Pelabuhan Tanjung Emas Kota Semarang. Jurnal Kesehatan Masyarakat (e-Journal) Volume
4, Nomor 1, Januari 2016 ( ISSN:23563346), 159-166. 2016.

6. Soenjono, S. J. Status Kerentanan Nyamuk Aedes sp. ( DIptera:Culicidae) Terhadap Malation dna KAtivitas Enzim Esterase Non Spesifik Wilayah Kerja Kantor Kesehatan Pelabuhan Bandar Udara Sam Ratulangi Manado. JKL Volume 1 No. 1 Oktober 2011, 1-5. 2011.

7. Georghio GP, S. T. Pest Resistance To Pesticides. Dalam M. R. Georghio GP, (editors) Pest Resistance To Pesticides (hal. 769). New York: Plenum Press. 1998.

8. WHO. Guidelines For Laboratory And Field Testing Of Mosquito Larvicides. World Health Organization Communicable Disease Control, Prevention And Eradication. 2005.

9. WHO. Monitoring and Managing Insecticide Resistance in Aedes Mosquito Population, Interim Guidance For Entomologists. Geneva: World Health Organization. 2016.

10. Wong, J., Stoddard, S. T., Astete, H. Oviposition Site Selection by the Dengue Vector Aedes aegypti and its Implications for Dengue Control. PLoS Neglected Tropical Diseases 5(4):e1015. doi:10.1371/journal.pntd.0001015, 1-12. 2011.

11. Hoel, D. F., J.Obenauer, P., Clark, M., Smith, R. Efficacy of Ovitrap Colors and Patterns for Attracting Aedes albopictus at Suburban Field Sites in North-Central Florida. Journal of the American Mosquito Control Association, 27(3) DOI: 10.2987/11-6121.1, 245-251. 2011.

12. WHO. Regional Office for South-East Asia. Comprehensive guidelines for prevention and control of dengue and dengue hemorrhagic fever. 2011.

13. Mulyatno, K. C., Yamanaka, A., Ngadino., Konishi, E. Resistance of Aedes aegypti (L.) Larvae To Temephos In Surabaya, Indonesia. Southeast Asian Journal of 
Tropical Medicine and Public Health, Vol 43, No.1: Januari, 29-33. 2012.

14. Kemenkes RI. Peratutan Menteri Kesehatan Republik Indonesia Nomor 44 tentang Penyelenggaraan Pelabuhan Dan Bandar Udara Sehat. Jakarta. 2014.

15. Indrayati, A., \& Setyaningsih, W. Penentuan Lokasi Prioritas Penanganan Kasus Demam Berdarah di Kota Semarang Berbasis Sistem Informasi Geografis. Forum Ilmu Sosial, FIS 40 (1), 56-67. 2013.

16. Khairunnisa, U., Wahyuningsih, N. E., \& Hapsari. Kepadatan Jentik Nyamuk Aedes sp. (House Index) Sebagai Indikator Surveilans Vektor Demam Berdarah Dengue di Kota Semarang. Jurnal Kesehatan Masyarakat (e-journal), Vol.5, No.5, (ISSN:2356-3346), Oktober, 906910. 2017.

17. Mulyowati, T. Populasi dan Status Resistensi Larva Aedes aegypti Terhadap Insektisida Organofosfat di Kecamatan Pati. Tesis. 2010.

18. Sulistyorini, E. Faktor Penentu Keberadaan Larva Aedes spp. Pada Daerah endemis Demam Berdarah Dengue Tertinggi dan Terendah di Kota Bogor. Tesis. Bogor: Institut Pertanian Bogor. 2016.

19. Notoatmodjo, S. Kesehatan Masyarakat dan Seni. Jakarta: Rineka Cipta. 2007.

20. Kemenkes RI. Peraturan Menteri Kesehatan RI No. 374/Menkes/SK/III/2010, tentang Pengendalian Vektor. Jakarta: Kemenkes RI. 2010.

21. Kemenkes RI. Modul Pengendalian Demam Berdarah Dengue. Jakarta, Indonesia: Direktorat Jenderal Pengendalian Penyakit dan Penyehatan Lingkungan. Kementerian Kesehatan Republik Indonesia. 2014. 